\title{
Existence and Development: The Value Attribution of Mozi's Educational Thought
}

\author{
LV Yan \\ Journal editorial department, Zaozhuang University \\ Zaozhuang, China
}

\begin{abstract}
Mohism, which rises in the Spring and Autumn Period, now ranks as a prominent school with Confucianism. However, there are great differences in the aims, goals and ways of education between Confucianism and Mohism. Mozi values people's livelihood and advocates harmony. He advocates the implementation of equal education for all. He supports general education and practical education for individuals and social development. He promotes education of universal values and education related to military theory and practice for the realization of interpersonal and international harmony. The Mohist disciples, who are "righteous, eloquent and knowledgeable", are virtuous, wise and brave. They are all good at practicing truth, academically and generously devoted to justice. They have become successful role models in the history of education in the Spring and Autumn Period. Mohist educational thought is of great enlightening significance to today's educational system and personnel training.
\end{abstract}

Keywords-Value people's livelihood; Education for all; General education; Practice consciousness

\section{INTRODUCTION}

During the Spring and Autumn Period, the administration of kingdoms was slack and academic schools were flourishing and contending. With the rise of multiculturalism, education also changed from the government to the private sector. The purpose, object and mode of education changed accordingly, basically completing the transformation from the integration of politics and religion, the integration of officials and teachers to the diversification of learning in the private sector. Mohism originated from Confucianism: "Confucian scholars of Mohism, by Confucius's art, thought that their rites disturbed but did not say, rich burial and poor people, (for a long time) to serve injuries and injuries, so back to the Tao and use Xia Zheng." ("Huai nanzi Yao Luexun") Mozi abandoned Confucianism and put forward Mohism because he was dissatisfied with the complicated rituals of Confucianism and the rituals of heavy burial at great financial cost. Confucius and Mozi were both prominent scholars at that time. Mozi was a great thinker, educator and scientist. As a new scholar class, living in chaotic times, Mozi thought and practiced wisely, and pursued his political ideal of sages all his life. He condemned offensive wars and advocated universal love. Moreover, Mozi received disciples from all walks of life, imparted academic knowledge, methods and skills, fostered humanistic spirit, and led them to practice Taoism, with a view to establishing an ideal society of justice, peace and mutual benefit. Based on the ideal political blueprint of Mohism, Mozi advocates global education, constructs a large education model shared by the whole people, training Mohist disciples in ideology, wisdom, will and practice, and forms an action team that is beneficial to the world, and assumes the responsibility of rebuilding order and rebuilding the country as Mohists. Looking back on the history of the Spring and Autumn Period from a modern perspective, Mozi's educational thoughts and achievements are enough to provide moral significance and reference value for the education of that era and future generations, no matter from the motivation of behavior and the strength of implementation. Mozi's educational thought is based on the people's livelihood and individual development concept, as well as economic concepts such as mutual benefit and sharing, which has a lasting enlightenment.

\section{The ThOUght of EDUCATION FOR ALL UNDER THE IDEAL OF A SACRED SOCIETY}

Mozi said that "the officials are impermanent and noble, but the people have no end" ("Shangxian Shang") ${ }^{[1]}$. It was intended to break down the noble and inferior hierarchy and aristocratic hereditary system since the Western Zhou Dynasty. In the construction of the political system, Mozi put forward the idea that the country should be governed by the wise and kings should get to know the wise and give him a role to play, which opened the door for the social sages to become officials, and made the officials no longer need to cultivate their family identity and aristocratic ladder. "Shangxian Shang" said: "In the ancient times, the Saint King was in charge of politics, virtue and talent were highly valued. People in farms and workshops could be officials, promoted to higher social rank, and were paid with high salary. The direct selection of talented people from the peasants and the humble people from industry and commerce was advocated. But virtue is not the only criterion, "Shang Tong" also said: "We can not govern our son's body, how can we govern our country? "Shangxian Shang" also stipulated the political character of the sages: intelligence, virtue and willpower. Education plays an important role in improving people's character. Therefore, in order to establish a government of wise men and realize the fair flow of social strata, Mozi advocated changing the unity and monopoly of the official school system since the Western Zhou Dynasty, eliminating the restrictions of country, region, origin and age, popularizing education for all, and making education shared at the grass-roots level of society. For this reason, Mozi advocated "educating people by advising Taoists". It was the responsibility of the clerical class to teach people. Mozi himself practiced collecting disciples widely and listed "Lord Wang" and "Pifu hikers" as objects of education. Historically, most of Mozi's disciples were "people from farms and workshops", such as Gao He and Xian Zishuo of the Qi people. There were also many officials from straw shoes weavers and 
mattress weavers. Mozi himself was also called a "humble guy" by the scholar-officials of Chu. It can be seen that as long as they are able to work hard, have the practical spirit of hardship and endurance, and faithfully perform the "moral" of Mohism, they can become disciples of Mohism. In addition, Mozi's educational concept is open, teaching according to different people and aptitude. It not only trains the virtuous sages and chivalrous men, but also trains the military, scientific and technological talents, farmers and personnel from all walks of life. Mozi's positive attitude towards the people and opening up school promoted the social stratum flow, broke the inherent hierarchical model and blood patriarchal restrictions of education since the Eastern Zhou Dynasty, and made education really go on the road of popularization and popularization.

\section{LABOR AND SKILLS EDUCATION IN THE POSITION OF MAINTAINING PEOPLE’S LIVELIHOOD}

Rousseau once said, "Only those who live by their own labor are truly free people." But facing the pressure of survival, freedom is a kind of extravagant hope. In an agricultural society which depends on nature for a living, labor is the most essential survival skill. Moreover, labor is not only a means to create material wealth, but also a means to develop human physical, intellectual and spiritual abilities, and to foster individuals' morality and personality. Therefore, Mozi's educational thought has obvious utilitarian orientation and extreme pragmatism. Mozi realized that human survival is the first important thing and food and clothing is the most realistic livelihood. Labor and production are the way to it. As a doer, Mozi clearly put forward that "Life flourishes in sweat. No sweat no life". "Fei Yue Shang" advocated that the world should do everything in its own way and be diligent in doing things. He opposed the exploitation of "greed for food, laziness in doing things", "dreaming of harvest without plowing". In agricultural production, Mozi advocated efficient use of land, increase agricultural labor force as much as possible, guided his disciples to "work as an early bird at dawn, end late at dusk." He also required that women to wake up early to spin and weave to ensure agricultural production capacity. Mozi highlighted the labor behavior of cultivation, harvesting and storage, which Confucius despised. In Mozi's opinion, only by building up the consciousness of working hard to become rich, simple and selfless, that the rich are not arrogant, and that the poor are not hungry, can we guarantee the minimum right to subsistence of the lower-class workers. In this regard, Mozi personally acted as an example for his disciples: Historically, Mozi "lived diligently and died poorly" and "took self-suffering to the extreme" (Zhuangzi) ${ }^{[2]}$.In addition, Mozi was born in a small handicraft industry, proficient in woodworking, car-making, leather, pottery, metallurgy, weaving, shoe-making and other skills, so in Mohist education the transfer of practical skills is also included. Mozi encouraged his disciples to follow their own business, divide their careers, and strive for self-support. As for the teaching methods of Mohism, some researchers said, "The teaching of Mohism to its apprentices is not only to teach principles, but also to pay attention to the training of technical operations. Today 'Mohist Classic' and 'Classic Theory' should be the teaching outline of the Mohist School at that time." [3] It can be seen that the transfer of Mohist craft skills involves not only theoretical study, illustration and interpretation, but also practical content such as hands-on operation and field exercises. Mohist education, which attaches great importance to physical labor and practical skills training, is the most basic training of survival ability, and the basic guarantee for solving people's livelihood problems under normal social conditions.

\section{Civil General EducAtion from the Perspective OF DEVELOPMENT}

Mozi is an encyclopedic scientist and educator. The educational goal of Mohist school is to cultivate generalists who support self-development and social development. Compared with Confucian education of ritual, music, shooting, imperial, book and number (six arts), the teaching content of Mohist school is broader, comprehensive and pragmatic. Mozi opposed the Confucian red tape, but Mozi also advocated moral cultivation. The salvation and concurrent scholar whom he respected as "the benefit of prospering the world, the harm of the world", the first condition was "good moral conduct". Therefore, the basis of Mozi's general education was moral conduct, followed by "argumentation, broad Taoism". That is, quick thinking, rich in argumentation, and possession of eloquence. Have extensive knowledge and skills. From the perspective of individual development, Mozi encouraged his disciples to be diligent in acquiring knowledge and actively becoming talented. The article in "Relatives" said: "Although there are virtuous rulers, they do not love ministers who have no merits; although there are loving fathers, they do not love children who have no merits." Mohism aimed to cultivate talented and promising scholars. Its subject content is very extensive, involving sociology, logic, mathematics, optics, acoustics, mechanics and psychology, etc ${ }^{[4]}$ Especially in the formal logic, Mohist first proposed the concept of "class, reason" to guide disciples to "observe class and reason" and acquire knowledge through direct and indirect experience, but to judge things on the basis of practice and avoid one-sided and subjective errors. In the later period, Mohist classics developed Mohist academic spirit. In this period, education also improved greatly in epistemology, logic and scientific and technological knowledge. In addition, Mohist school advanced Mohist natural outlook, and gained new recognition in the relationship between time, space and movement. Mohist classics became the complete teaching materials of Mohist education in the later period, improving the content system of Mohist education as well.

Compared with the training of shooting and imperial skills set up by Confucianism for noble children, Mohism has a more perfect system of military education, training military science and technology talents for war from theory to practice. Universal ideas such as universal love and non-offensive are the common beliefs of Mohist disciples, but it is an indisputable fact in history to stop war. Therefore, Mohism not only studied military diplomacy theory, but also devoted itself to the study of military tactics and tactics. Mohism is good at manufacturing machinery, especially military defense equipment. On the one hand, Mozi taught his disciples lobbying and defensive tactics to prevent war; on the other hand, he studied engineering technology and defensive tactics intensively, and wrote "Best City Gate" to teach his disciples defensive theory. Mozi also designed and manufactured a 
variety of defensive devices, such as throwing cars, crossbows, transmitters and so on, to teach his disciples to prepare for war. In terms of education and cultivation of military engineering talents, Mohist school is indeed a pioneer in Spring and Autumn Period.

Mozi is a real educator who emphasizes practicality and practice. He trains his disciples not only with knowledge, ability and skill, but also with the spirit of practice and righteousness of practice. He demands his disciples with "the unity of ambition and merit", "Being virtuous is more important than being knowledgeable" ("self-cultivation"). Mozi once lamented the disagreement of words and deeds, affirming the meaning and importance of action. "Do it if benefiting others, stop it if harming others"("Fei Yue Shang"), so benefiting people is the virtue and motive of Mohist school. Mozi also pays attention to cultivating his disciples' spiritual personality, upholding righteousness, valiance and courage, requiring them to "engage forcefully", "be powerful in order to be respected, if weak, will be humiliated" ("Destiny"). Mozi does not advocate exploring survival in meditation and compassion, but actively engage in what one wants to do. And this is the ultimate value and intention of self-existence. So there are many warriors among his disciples, "Around eighty to one hundred disciples, all can go through fire and water ." (Huainanzi Tai Xun)

\section{PUBLIC EDUCATION AND PUBLIC INTERESTS EDUCATION FROM THE PERSPECTIVE OF HARMONY CONSCIOUSNESS}

Mozi's thought is based on the establishment of a fair and just, harmonious society. He tries to achieve the best arrangement of human society by establishing his own moral system. Mozi holds that public interest is justice, and Mohist justice is the principle of life and the spirit of altruism based on the thought of universal love, non-happiness, saving and simple burial. ${ }^{[5]}$ In order to realize the harmony and social harmony of the world, Mozi advocated that no country is big or small, no people are noble or humble, and proposed that "today, all countries, big or small, all cities in this universe; all people, young, noble or humble, all subjects under the sky"(Fayi). On the basis of equality of social strata, Mozi further proposed social ethical requirements to achieve interpersonal harmony that "the emperors should be generous and subjects should be loyal, and fathers should be kind and sons and brothers should be filial" ("Tian Zhizhong"). In addition, Mozi shaped the people's humanistic spirit and coexistence consciousness with the thought of both love and non-attack, advocated the interpersonal communication principle of "the strong, not insult the weak; the poor, not rob the rich; the noble, not be arrogant; the wise, not bully the foolish", with a view to forming a benign social ecology of "spare effort to help each other, separate the surplus from the rest of the wealth, and teach each other good and moral principles"; and advocated the idea of respecting the virtuous to establishing social fairness, justice and political equality, thus forming a vibrant and dynamic regime mechanism. Moreover, Mozi's thought of co-existence and co-construction of non-attack, anti-war and mutual benefit is of great universal value. Mozi believes that the direct consequence of war is "farmers can not farm, women can not weave", which is harmful and is against the law. In
"Tian Zhi", Mozi attributed his will to destiny and had limitations in his understanding. But in the Spring and Autumn Period, Mozi taught the people with this idea, and if people accepted this and applied to diplomatic relations, "take neighbors as neighbors", will war took place? Mozi's thought is full of humanistic feelings of saving the times and helping the people. Its basic point is the word "harmony". The goal is to balance the relationship between justice and benefit. In Mozi's view, justice is benefit. Justice of benefiting the world and altruism, realizing the public welfare of the whole society will ultimately achieve self-interest. Mozi's moral thought has become the common belief and spiritual pursuit of Mohist members in the field of preaching and teaching. Qin Huali, Geng Zhuzi, Gong Shangguo, Gao Shizi, Gao Sunzi and Sui Caozi are all excellent disciples of Mohism. As a compilation of teaching materials for later Mohist school, Mohist Classic eliminates the ideal elements in Mozi's thought of righteousness and benefit, advocates that righteousness should be based on "ambition and merit", and holds that "ambition" motivated by subjective motives conforms to the external value of "merit" before it becomes righteousness. To some extent, profit is regarded as a public interest, and the value of altruism is emphasized.

Mohist doctrine and its educational philosophy aim at promoting the humanistic spirit of universal love, fairness and justice, and mutual benefit, establishing a world of interpersonal harmony, national harmony, and realizing a better and equal living environment ${ }^{[6]}$ It is impossible for Mohist school to set up an academy and teach like Confucius. Mozi benefits the world all his life and he lead his disciples to lobby around. It is impossible for Mohist school to engage in stable teaching activities. Its teaching is flexible, and timely, just as the American practical educator John Dewey said, "Education is life". The essence of education is to learn by doing it. The learning of Mohist disciples should also be completed in the course of following Mohist principles and running on the road of righteousness.

\section{CONCLUSION}

Mohist education is a form of folk education formed during the periods of the decline of the kingdom of the Eastern Zhou Dynasty, the brewing of a new regime and the cultural transformation from monism to pluralism. Mohist thought mainly represents the survival appeals of the lower classes and small private owners, which is pure and simple. In terms of education, Mozi advocated the establishment of a holistic and panoramic education model, which treating the common people equally. He promoted the Mohist idea of saving from the perspective of improving people's livelihood and steady social development. He opposed self-interest at the cost of others. He advocated the principle of "working people live" and economic sharing with fraternity. In order to build a harmonious world, he opposed that the strong bullying the weak, the old bullying the young. Mozi disliked empty talk . He taught in action, and he was very humble. However, he trained a group of Mohist followers with wisdom, benevolence and courage. On the stage of the Spring and Autumn Period, Mozi performed a warm-blooded, generous and courageous drama. The short history of Mohism has become an indispensable part of Chinese civilization. It is a mirror 
reflecting the Spring and Autumn Period. Today, we still need to study and explore with high respect, the value and significance of Mohist educational thought in the construction of modern civilization, and reproduce the glory of Mohism which has been covered up by history for a long time.

\section{ACKNOWLEDGEMENT}

This article was presented at the 2018 2nd International Conference on Economic Development and Education Management. I wish to thank the academic peers for their insightful comments at the conference. I am grateful to the editor of Advances in Social Science, Education and Humanities Research and anonymous reviewers for their suggestions and efforts.

\section{REFERENCES}

[1] Y.J.Wu. Mozi Jiao Zhu. Beijing: Zhonghua Publishing House, 2006. (In Chinese)

[2] H.R.Yao. Zhuangzi Zhi Jie. Shanghai: Fudan University Press, 2000, pp860. (In Chinese)

[3] J. Y.Ren,X.L.Sun,J.F.Lin. Mozi Yu Mo Jia. Beijing: Beijing Publishing House, 2016, pp97. (In Chinese)

[4] J.f. Zhan. Mozi De Zhe Xue Yu Ke Xue. Beijing:The People's Publishing House, 1981. (In Chinese)

[5] Z.1. Xing. Mozi Ping Zhuan. Nanjing: Nanjing University Press, 2011. (In Chinese)

[6] W. Chen. Mozi:Jian Ai Ren Sheng. Wuhan: Yangzi Liberal Arts Publishing House, 1997. (In Chinese) 